\title{
A rare case of acute abdomen in an adult: spontaneous Meckel's diverticulum perforation
}

Serhat Doğan ${ }^{1}$, Ebubekir Gündeş², Hüseyin Gülcan ${ }^{3}$, Mehmet Barburoğlư ${ }^{4}$, Onur Oral ${ }^{5}$

${ }^{1}$ Department of General Surgery, Malatya Education and Research Hospital, Malatya, Turkey

2Department of Gastroenterological Surgery, Kartal Training and Research Hospital, Istanbul, Turkey

${ }^{3}$ Department of General Surgery, Malatya Training and Research Hospital, Malatya, Turkey

${ }^{4}$ Department of Radiology, Private Medicine Hospital, Istanbul, Turkey

${ }^{5}$ Deprtment of Pathology, Viranşehir State Hospital, Sanliurfa, Turkey

Submitted: 8 April 2017

Accepted: 24 August 2017

Arch Med Sci Civil Dis 2017; 2: e135-e138

DOI: https://doi.org/10.5114/amscd.2017.70883

Copyright @ 2017 Termedia \& Banach

Meckel's diverticulum (MD) is the most common congenital anomaly of the gastrointestinal system. It is located approximately $60-80 \mathrm{~cm}$ proximal to the cecum, on the antimesenteric face of the small bowels. The average length is $4-6 \mathrm{~cm}$ and it is a real diverticulum. It occurs if the omphalomesenteric tract does not close between the $5^{\text {th }}$ and $7^{\text {th }}$ weeks of intrauterine life [1]. Meckel's diverticulum was first described in the $16^{\text {th }}$ century by Fabricus Hildanus. It was embryologically described and named by the German Johann Friedrich Meckel in 1809 [2, 3]. The rule of $2 \mathrm{~s}$ is a useful memory aid. MD occurs in $2 \%$ of the population, is 2 inches $(5 \mathrm{~cm})$ long, 2 feet $(60 \mathrm{~cm})$ from the ileocecal valve, two thirds have ectopic mucosa, 2 types of ectopic tissue are commonly present (mostly gastric and pancreatic) and $2 \%$ become symptomatic [4-6].

Patients usually have nonspecific complaints such as nausea, vomiting, abdominal pain, and loss of appetite [7]. These findings were exacerbated after perforation and abdominal symptoms may progress. Many complications occur such as massive gastrointestinal hemorrhage [8], cecal volvulus [9], ileus [10], subphrenic abscess [11], small bowel torsion due to MD [12], and perforation, as in our case and in the literature. The mortality rate is reported to be between $1.6 \%$ and $7.7 \%$ [13]. Mortality usually occurs in delayed cases and with intestinal gangrene [7]. Here we present our case, which was diagnosed as spontaneous MD perforation due to acute abdomen, in light of the literature.

A 27-year-old male patient presented with abdominal pain, anorexia, nausea and fever to the emergency department. The patient was examined in emergency service. On physical examination, rebound tenderness and guarding was positive. The patient had an acute abdomen. There was nothing in his anamnesis. Digital rectal examination was performed. The rectum was empty and without hemorrhage. In the patient's blood tests, white blood count (WBC) was $26.5210^{3} / \mathrm{Ul}$, glucose $131 \mathrm{mg} / \mathrm{dl}$, lactic dehydrogenase $350 \mathrm{U} /$, creatine kinase $2742 \mathrm{U} / \mathrm{l}$, C-reactive protein $4.89 \mathrm{mg} / \mathrm{dl}$, sodium $135 \mathrm{mmol} / \mathrm{l}$. The patient's complete urinalysis included 7 erythrocytes/HPF and 3 leukocytes/HPF. Nothing was detected in the direct abdominal X-ray (Figure 1). Abdominal ultrasonography report of the patient: "Mesenteric echo is heterogeneous

\author{
Corresponding author: \\ Serhat Doğan \\ Department of \\ General Surgery \\ Malatya Education \\ and Research Hospital \\ 44000 Malatya, Turkey \\ Phone: +90 5069306797 \\ E-mail: drserhatdogan@ \\ gmail.com
}




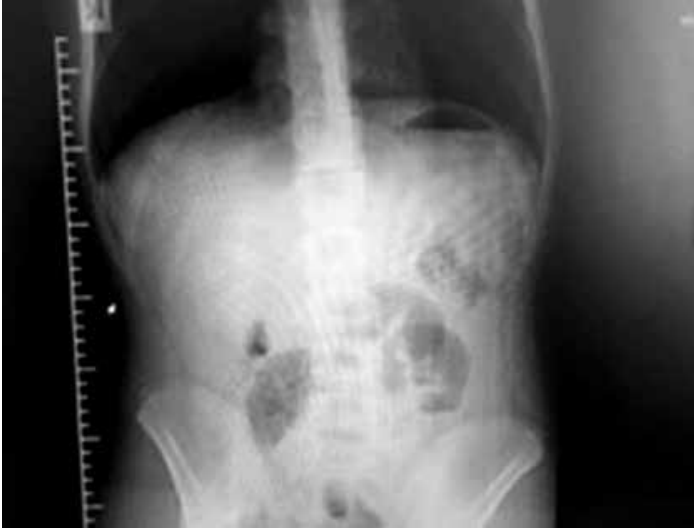

Figure 1. Direct abdominal graphy

in the lower right quadrant. Appendices cannot be visualized. Plastrone is suspicious. Tomography is recommended." Then abdominal computed tomography (CT) was performed. Computed tomography revealed perforation and minimal fluid between the intestines (Figures 2 and 3). The patient was prepared for an emergency operation. Laparotomy was performed and in the operation an MD perforation was found approximately 60-70 $\mathrm{cm}$ to the cecum. Photographs were taken perioperatively (Figures 4 and 5).

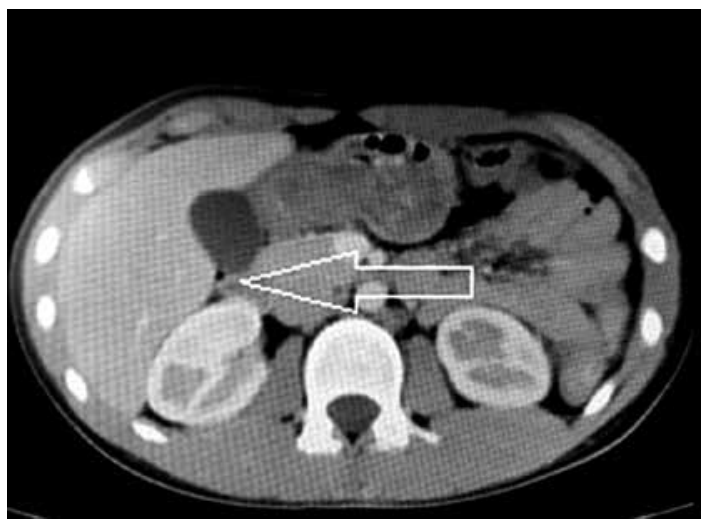

Figure 2. Perforation on abdominal CT (air bubbles on the lower part of the gall bladder)

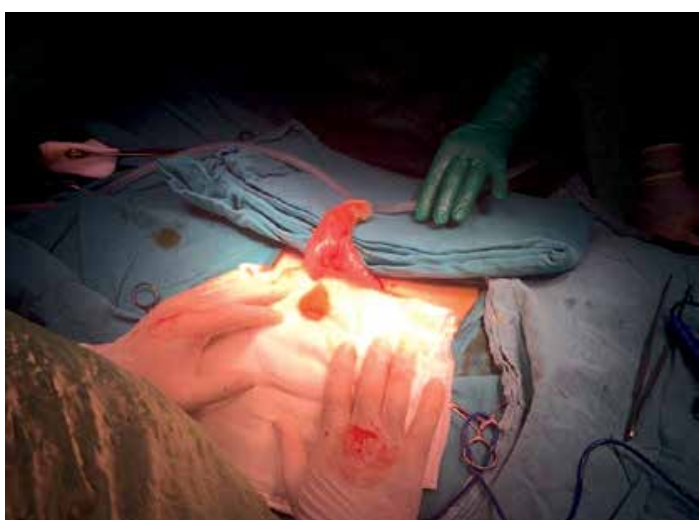

Figure 4. Photographs of perioperative Meckel's diverticulum
There were fibrin plates together. No additional pathology was found in exploration. We decided to perform resection and anastomosis. The abdomen was washed with plenty of physiological saline solution. One drain was placed in the pelvis. After the operation the patient was referred to an infectious diseases specialist for antibiotic therapy selection. Antibiotic therapy was administered. On the third postoperative day the drain was shortened because the drain was clear. On the fourth postoperative day oral intake was started as regime 1 . On the postoperative fifth day the drain was pulled and the oral intake resumed as normal. The WBC value fell to within normal limits 6 days after the operation. The patient was discharged on the $7^{\text {th }}$ day. Sutures were taken out on postoperative day 15 . Blood levels were completely normal. Pathological examination revealed MD.

Meckel's diverticulum is a congenital anomaly commonly seen in the gastrointestinal tract. The rate in the population is approximately $2 \%(1-3 \%)$ [14]. It occurs as the result of the omphalomesenteric tract not closing [1]. It is 3 times more frequent in men [15].

In intrauterine life in the early weeks, the fetus takes nutrients from the yolk sac via the vitelline duct. This tube disappears in the $7^{\text {th }}$ week of preg-

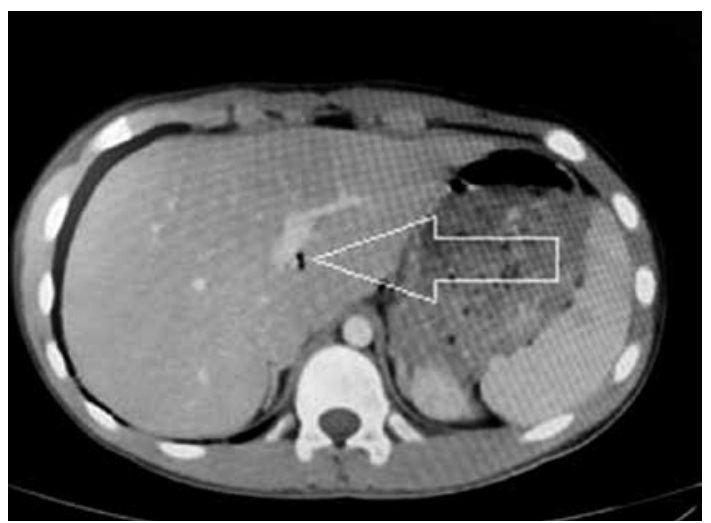

Figure 3. Perforation on abdominal CT (air flash in the liver hilus)

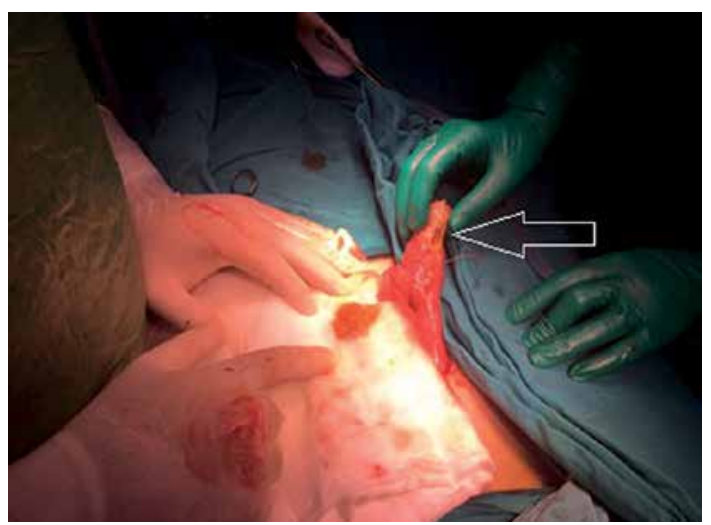

Figure 5. Photographs of perioperative Meckel's diverticulum perforation 
nancy. If not, MD occurs [1]. Meckel's diverticulum is frequently located $40-60 \mathrm{~cm}$ proximal to the ileocecal valve on the antimesenteric face of the ileum. The size of the diverticulum varies within $1-10 \mathrm{~cm}$, often $6 \mathrm{~cm} \mathrm{[16].}$

Hemorrhage is a frequent complication. Bleeding in the form of fresh blood in the child may be confused with invagination. In adults, melena can be seen with abdominal pain [17]. There are cases reported in the literature that cause massive gastrointestinal bleeding [8]. Bleeding is mainly due to the ectopic tissue of the diverticula. The most common is stomach tissue followed by pancreatic tissue. Tissue enzyme damage of the small intestine is responsible for this [18]. Diverticulitis is a common complication [19].

Occasionally, perforations associated with a fish follicle $[19,20]$, due to a blunt abdominal trauma [21] or button cell [22, 23] and spontaneous $[24,25]$ cases are found in the literature. Resection is recommended for patients with complicated MD during the operation, and resection for incidental cases has been discussed. The operative technique can vary depending on the patient's condition and because of perforation during the operation. The presence of symptoms is very important. The surgeon must ensure that the diverticular structure is completely removed in the operation and should not narrow the passage.

Schlicke and Johnston advised elective diverticulectomy for cases in the small intestines during laparotomy [26]. However, Cullen et al. recommend resection for all coincidentally detected MDs in patients below the age of 80 [27]. Park et al. recommended resection in symptomatic cases. Asymptomatic and uncomplicated diverticula suggest simple diverticulectomy [15].

Contrary to these ideas, Soltero and Bill reported that they rarely operated for prophylactic resection except for definite acute abdomen [28].

As a result, segmental small bowel resection or diverticulectomy may be performed to include the diverticulum as a surgical treatment. The surgical technique should be decided intraoperatively according to the patient's pathology. It should not be forgotten that there may be a complication due to MD in clinically unexplained cases.

\section{Conflict of interest}

The authors declare no conflict of interest.

\section{References}

1. Peoples T, Lichtenberger ET, Dunn M. Incidental Meckel's diverticulectomy in the adults. Surgery 1995; 118 : 649-52.

2. Meckel JF. Über die Divertikel am Darmkanal. Archiv für die Physiologie 1809; 9: 421-53.
3. Opitz JM, Schultka R, Gobbel L. Meckel on developmental pathology. Am J Med Genet A 2006; 140: 115-28.

4. Sagar J, Kumar V, Shah DK. Meckel's diverticulum: a systematic review. J R Soc Med 2006; 99: 501-5.

5. Stallion A, Shuck JM. Meckel's diverticulum. In: Surgical Treatment: Evidence-Based and Problem-Oriented. Holzheimer RG, Mannick JA (eds). Zuckschwerdt, Munich 2001.

6. Podolsky D, Camilleri M, Fitz JG, Kalloo A, Shanahan F, Wang T. Yamada's Textbook of Gastroenterology. Willey $6^{\text {th }}$ ed. 2015; 817.

7. Cullen JJ, Kelly KA. Current management of Meckel's diverticulum. Adv Surg 1196; 29: 207-14.

8. Lichtstein DM, Herskowitz B. Massive gastrointestinal bleeding from Meckel's diverticulum in a 91-year-old man. South Med J 1998; 91: 753-4.

9. Neidlinger NA, Madan AK, Wright MJ. Meckel's diverticulum causing cecal volvulus. Am Surg 2001; 67: 41-3.

10. Tekin A, Küçükkartallar T. Meckel Divertikülü’nün Nadir Bir Komplikasyonu: Illeus. Fırat Tıp Dergisi 2008; 13: 062-4.

11. Kundra R, Wardhan H. Perforated Meckel's diverticulum presenting as subphrenic abscess. Indian J Pediatr 2001; 68: 353-4.

12. Aldemir M, Yılmaz G, Girgin S. Meckel divertikülüne bağı ince barsak torsiyonu. Kolon Rektum Hast Der 2000; 10: 94-5.

13. Peoples T, Lichtenberger ET, Dunn M. Incidental Meckel's diverticulectomy in the adults. Surgery 1995; 118 : 649-52.

14. Perlman JA, Hoover HC, Safer PK. Femoral hernia with strangulated Meckel's diverticulum (Littre's hernia). Am J Surg 1980; 139: 286-9.

15. Park JJ, Wolff BG, Tollefson MK, Walsh EE, Larson DR. Meckel diverticulum: the Mayo Clinic experience with 1476 patients. Ann Surg 2005; 241: 529-33.

16. Groebli Y, Bertin D, Morel P. Meckel's diverticulum in adults: retrospective analysis of 119 cases and historical review. Eur J Surg 2001; 167: 518-24.

17. Turgeon DK, Barnett NL. Meckel's diverticulum. Am J Gastroenterol 1990; 85: 77-81.

18. Yahchouchy EK, Marano AF, Etienne JCF, Fingerhut AL. Meckel's diverticulum. J Am Coll Surg 2001; 192: 658-62.

19. Wong JH, Suhaili DN, Kok KY. Fish bone perforation of Meckel's diverticulum: a rare event? Asian J Surg 2005; 28: 295-6.

20. Dimitriou I, Evaggelou N, Tavaki E, Chatzitheoklytos E. Perforation of Meckel's diverticulum by a fish bone presenting as acute appendicitis: acase report. J Med Case Rep 2013; 7: 231.

21. Ekwunife CN, Mbadugha TN, Ogbue UN. Isolated Meckel's diverticulum perforation as a sequel to blunt abdominal trauma: a case report. J Med Case Rep 2014; 8: 111.

22. Ozokutan BH, Ceylan H, Yapıcı S, Sımsık S. Perforation of Meckel's diverticulum by a button battery: report of two cases. Ulus Travma Acil Cerrahi Derg 2012; 18: 358-60.

23. Karaman A, Karaman I, Erdoğan D, et al. Perforation of Meckel's diverticulum by a button battery: report of a case. Surg Today 2007; 37: 1115-6.

24. Grasso E, Politi A, Progno V, Guastella T. Spontaneous perforation of Meckel's diverticulum: case report and review of literature. Ann Ital Chir 2013; 84(ePub). pii: S2239253X13020902. 
25. Farah RH, Avala P, Khaiz D, et al. Spontaneous perforation of Meckel's diverticulum: a case report and review of literature. Pan Afr Med J 2015; 20: 319.

26. Schlicke CP, Johnston EW. Experiences with Meckel's diverticulum. Surg Gynecol Obstet 1968; 126: 91-3.

27. Cullen JJ, Kelly KA, Moir CR, Hodge DO, Zinsmeister AR, Melton LJ 3rd. Surgical management of Meckel's diverticulum. An epidemiologic, population-based study. Ann Surg 1994; 220: 564-9.

28. Soltero MJ, Bill AH. The natural history of Meckel's diverticulum and its relation to incidental removal. Am J Surg 1976; 132: 168-73. 